\title{
HUBUNGAN DUKUNGAN BAPAK DENGAN STATUS GASTROENTERITIS PADA BALITA DI UPTD PUSKESMAS LUAHAGUNDRE
}

\author{
Cristina Magdalena Tampubolon \\ Dosen Prodi S1Keperawatan, STIKes Imelda, Jalan Bilal Nomor 52 Medan \\ Email: grebyon@gmail.com
}

\begin{abstract}
ABSTRAK
Gastroenteritis merupakan proses peradangan yang terjadi pada daerah lambung dan usus yang biasanya disertai dengan gejala diare secara terus menerus dan paling sering sering terjadi pada balita. Perawatan kesehatan balita dalam keadaan gastroenteritis merupakan salah satu aspek perawatan orang tua (ibu dan bapak) yang dapat mempengaruhi status gizi balita dalam penyembuhan penyakitnya sehingga memperbaiki status gastroenteritis yang harus sangat diperhatikan oleh keluarga khususnya ibu yang memiliki balita. Rumusan masalah penelitian adalah bagaimana hubungan dukungan bapak dengan status gastroenteritis. Tujuan penelitian untuk menguji hubungan dukungan bapak dengan status gastroenteritis pada ibu yang memiliki balita yang mengalami gastroenteritis.Jenis penelitian adalah korelasi dengan pendekatan cross sectional. Penelitian dilaksanakan di UPTD Puskesmas Luahagundre, Sampel adalah seluruh ibu yang memiliki balita yang mengalami gastroenteritis tahun 2018 sebesar 51 orang. Alat pengumpulan data menggunakan kuesioner dukungan bapak dan lembar observasi status gastroenteritis. Uji yang digunakan adalah chi-square.Hasil penelitian menunjukkan Ada hubungan yang signifikan antara dukungan bapak dengan sattus gastroenteritis ( $p$ value $<0,05$ ) dengan Rasio Prevalensi $(R P)=9,6$ artinya dukungan bapak buruk kepada ibu yang memiliki balita yang mengalami gastroenteritis mempunyai risiko 9,6 kali balita yang gastroenteritis mengalami dehidrasi berat dibandingkan dengan dukungan bapak yang diterima ibu baik.Kesimpulan penelitian adalah ada hubungan yang signifikan antara dukungan bapak dengan status gastroenteritis (p value $<0,05$ ) dengan Rasio Prevalensi $(R P)=9,6$. Disarankan kepada keluarga lebih aktif dalam mencari informasi tentang pentingnya dukungan bapak kepada ibu dalam melakukan perawatan bagi balita yang sedang mengalami penyakit gastroenteritis untuk mencegah terjadinya dehidrasi berat.
\end{abstract}

Kata Kunci: Dukungan Bapak, Status Gastroenteritis, Balita

\section{PENDAHULUAN}

Penyakit gastroenteritis merupakan salah satu penyakit tropis yang menjadi penyumbang utama ketiga pada angka kesakitan dan kematian balita di dunia. Balita merupakan kelompok umur yang rentan penyakit gastroenteritis (diare) yang diakibatkan infeksi yang masih merupakan masalah kesehatan masyarakat, perlu dicari penyebab dan solusi untuk penyembuhannya (Kemenkes RI, 2013).Menurut World Health Organization (WHO) tahun 2013, memperkirakan 4 milyar kasus gastroenteritis terjadi di dunia dan sebanyak 2,2 juta penderita meninggal dunia serta sebagian besar terjadi pada balita. Jadi penyakit gastroenteritis masih merupakan masalah kesehatan masyarakat, baik ditinjau dari angka morbiditas (kesakitan) dan angka mortalitas (kematian) serta Kejadian Luar Biasa (KLB).Jumlah penderita pada KLB gastroenteritis tahun 2013 menurun secara signifikan dibandingka tahun 2012 dari 1,654 kasus menjadi 646 kasus pada tahun 2013. KLB gastroenteritis pada tahun 2013 terjadi di 6 provinsi dengan terbanyak terjadi di Jawa Tengah yang mencapa 294 kasus, sedangkan angka mortalitas (kematian) akibat KLB gastroenteritis tertinggi terjadi di Sumatera Utara yaitu sebesar 11,76\%.Praktik keluarga dalam hal pengobatan diare juga masih rendah. Padahal keluarga merupakan unsur penting dalam perawatan anak. Anak selalu membutuhkan orang tua selama di rumah sakit seperti dalam aktivitas bermainatau program perawatan lainnya seperti pengobatan. Keterlibatan orangtua dan 
kemampuan keluarga dalam merawat merupakan dasar dalam pemberian asuhan keperawatan yang berfokus pada keluarga (Hidayat, 2008).

Berdasarkan hasil survey di UPTD Puskesmas Luahagundre, dimana terjadi peningkatan kasus gastroenteritis dari tahun sebelumnya yaitu tahun 2016 sebanyak 455 kasus dan tahun 2017 sebanyak 460 kasus pada balita. Ibu yang memiliki balita di wilayah kerja Puskesmas Aek Batu sekitar 80 $\%$ ibu tidak melakukan air susu ibu (ASI) eksklusif, dengan kata lain sudak memberikan makanan pendamping ASI (MPASI) dibawah usia 6 bulan. Pada bulan Januari tahun 2018 ditemukan 58 kasus dengan kasus kematian balita akibat gastroenteritis tidak ditemukan. Walaupun balita yang mengalami gastroenteritis tidak ditemukan kasus kematian tetapi angka kesakitan masih cukup tinggi.

Berdasarkan hasil wawancara yang dilakukan terhadap lima ibu yang memiliki balita yang sedang mengalami gastroenteritis di UPTD Puskesmas Luahagundre diperoleh hasil yaitu tiga dari lima ibu yang memiliki balita yang sedang mengalami gastroenteritis ditemani oleh bapak atau suami dan dua diantaranya mengatakan bahwa suami sangat mendukung dalam pengobatan balita gastroenteritis dengan selalu memperhatikan keadaan anak, mendukung biaya, dan rutin menemani ibu atau istri untuk mengobati anak yang mengalami gastroenteritis dan dua diantaranya didapati anak dengan dehidrasi ringan.

Berdasarkan Latar Belakang diatas maka penulis tertarik untuk melakukan penelitian dengan judul "Hubungan Dukungan Bapak dengan Status Gastroenteritis pada Balita di UPTD Puskesmas Luahagundre".

Berdasarkan latar belakang yang telah dikemukakan, maka yang menjadi rumusan masalah adalah bagaimana hubungan dukungan bapak dengan status gastroenteritis pada Balita di UPTD Puskesmas Luahagundre.

\section{Tujuan Penelitian}

\section{Tujuan Umum}

Penelitian ini bertujuan untuk mengetahuihubungan dukungan bapak dengan status gastroenteritis pada Balita di UPTD Puskesmas Luahagundre.

Tujuan Khusus

1. Mendeskripsikan dukungan bapak pada Balita di UPTD Puskesmas Luahagundre.

2. Mendeskripsikan gastroenteritis pada Balita di UPTD Puskesmas Luahagundre.

3. Menguji hubungan dukungan bapak yang baik dengan status gastroenteritis pada Balita di UPTD Puskesmas Luahagundre.

\section{Hipotesis Penelitian}

Hipotesis dalam penelitian ini adalah ada hubungan dukungan bapak yang baik dengan status gastroenteritis pada Balita di UPTD Puskesmas Luahagundre.

\section{METODE}

Jenis Penelitian ini merupakan penelitian kuantitatif dengan menggunakan desain korelasi dengan pendekatan pengamatan sewaktu (cross sectional). Penelitian ini bertujuan untuk menganalisis hubungan dukungan bapak dengan proses status gastroenteritis pada balitadi UPTD Puskesmas Luahagundre.Populasi dalam penellitian ini adalah seluruh ibu yang memiliki balita yang sedang rawat inap dengan diagnosa penyakit gastroenteritis di Puskesmas Luahagundre. Selama tiga bulan terakhir balita yang berobat dengan gastroenteritis 173 orang, jadi dalam satu bulan sekitar 58 orang, dengan teknik non probability sampling jenis purposive sampling yang memenuhi kriteria inklusi yaitu 51 orang.

Instrumenpengukuran data dalam penelitian ini menggunakan kuesioner terstruktur yang dikembangkan berdasarkan komponen variabel dukungan bapak dan variabel status gastroenteritis pada balita.Uji statistik yang digunakan yaitu ujichi squaredengan taraf kepercayaan $95 \%$ atau taraf signifikan $\alpha=0,05$.Pengujian hipotesis penelitian dilakukan dengan menentukan derajat kepercayaan atau Confidence Interfal (CI) dengan interpretasi Rasio Prevalens (RP) sebagai berikut: $\mathrm{RP}=1$, artinya tidak ada hubungan antara dukungan bapak yang baik dan status gastroenteritis; RP > 1,artinya terdapat hubungan meningkatkan atau searah 
antara dukungan bapak yang baik dan status gastroenteritis; RP $<1$, artinya terdapat hubungan yang menurunkan angka resiko atau berlawanan antara dukungan bapak yang baik dan status gastroenteritis.

\section{HASIL}

Analisis Univariat

Karakteristik responden

Tabel 1. Karakteristik Ibu yang Memiliki Balita yang Mengalami Gastroenteritis Berdasarkan Umur, Pendidikan, Pekerjaan, Umur Balita, Berapa Kali Mengalami Gastroenteritis di UPTD Puskesmas Luahagundre Tahun 2018

\begin{tabular}{|c|c|c|c|}
\hline \multirow{5}{*}{$\begin{array}{l}\text { No } \\
1 \\
\end{array}$} & Karakteristik & f & $(\%)$ \\
\hline & Umur (Tahun) & & $h$ \\
\hline & $21-30$ & 26 & 51,0 \\
\hline & $31-40$ & 21 & 41,2 \\
\hline & $41-50$ & 4 & 7,8 \\
\hline \multirow[t]{4}{*}{2} & Pendidikan & & \\
\hline & SMP & 15 & 29,4 \\
\hline & SMA & 32 & 62,7 \\
\hline & PT & 4 & 7,9 \\
\hline \multirow[t]{3}{*}{3} & Pekerjaan & & \\
\hline & Bekerja & 47 & 92,2 \\
\hline & Tidak bekerja & 4 & 7,8 \\
\hline \multirow[t]{5}{*}{4} & Umur Balita (B & & \\
\hline & $13-24$ & & 37,3 \\
\hline & $25-36$ & 20 & 39,2 \\
\hline & $37-48$ & 2 & 3,9 \\
\hline & $49-60$ & 10 & 19,6 \\
\hline \multirow[t]{3}{*}{5} & $\begin{array}{l}\text { Berapa kali Me } \\
\text { Gastroenteritis }\end{array}$ & & \\
\hline & 1-2 kali & 39 & 76,5 \\
\hline & 3-4 kali & 12 & 23,5 \\
\hline
\end{tabular}

Tabel 1 menunjukkan bahwa dari $51 \mathrm{ibu}$ yang memiliki balita yang mengalami gastroenteritis sebagian besar berumur 21-30 tahun sebanyak 26 orang $(51,0 \%)$, berdasarkan pendidikan sebagian besar lulusan SMA sebanyak 32 orang $(62,7 \%)$, berdasarkan pekerjaan sebagian besar bekerja sebanyak 47 orang $(92,2 \%)$, berdasarkan umur balita sebagian besar berumur 25-36 bulan sebanyak 20 orang $(39,2 \%)$, dan berdasarkan berapa kali mengalami gastroenteritis sebagian besar 1-2 kali sebanyak 39 orang $(76,5 \%)$.

\section{Variabel Dukungan Bapak}

Tabel 2. Distribusi Frekuensi Dukungan Bapak di UPTD Puskesmas Luahagundre Tahun 2018

\begin{tabular}{lcc}
\hline Dukungan Bapak & f & Persentase (\%) \\
\hline Baik & 41 & 80,4 \\
\hline Buruk & 10 & 19,6 \\
\hline \multicolumn{1}{c}{ Tabel 2 men }
\end{tabular}

Tabel 2 menunjukkan bahwa dari $51 \mathrm{ibu}$ yang memiliki balita yang mengalami gastroenteritis lebih tiga perempat ibu menerima dukungan bapak baik sebanyak 41 orang $(80,4 \%)$ dan hampir seperempat ibu yang memiliki balita yang mengalami gastroenteritis menerima dukungan bapak buruk sebanyak 10 orang $(19,6 \%)$.

\section{Variabel Status Gastroenteritis}

Tabel 3. Distribusi Frekuensi Status Gastroenteritis di UPTD Puskesmas Luahagundre Tahun 2018

\begin{tabular}{lcc}
\hline $\begin{array}{c}\text { Penyembuhan Luka } \\
\text { Sectio Caesarea }\end{array}$ & f & $\begin{array}{c}\text { Persentase } \\
(\%)\end{array}$ \\
\hline Dehidrasi ringan & 42 & 82,4 \\
\hline Dehidrasi berat & 9 & 17,6 \\
\hline
\end{tabular}

Tabel 3 menunjukkan bahwa dari $51 \mathrm{ibu}$ yang memiliki balita yang mengalami gastroenteritis lebih dari tiga perempat balita mengalami dehidrasi ringan sebanyak 42 orang $(82,4 \%)$ dan hampir seperempat balita mengalami dehidrasi berat sebanyak 9 orang $(217,6 \%)$.

Analisis Bivariat

Tabel 4. Hubungan Dukungan Bapak dengan Status Gastroenteritis di UPTD Puskesmas Luahagundre Tahun 2018

Variabel Status Gastroenteritis RP $\quad p$
Dehidrasi Dehidrasi Total

\begin{tabular}{lllll} 
Ringan & \multicolumn{2}{c}{ Berat } & & \\
\hline n $\%$ & n & $\%$ & n & $\%$
\end{tabular}

\begin{tabular}{llllllll}
\hline \multicolumn{2}{l}{ Dukungan Bapak } \\
\hline Baik & 40 & 97,6 & 1 & 2,4 & 41 & 100 & $9,60,000$ \\
\hline Buruk & 1 & 10 & 9 & 90 & 10 & 100 & \\
\hline
\end{tabular}

Tabel 4 menunjukkan hubungan antara dukungan bapak yang diterima ibu yang memiliki balita yang mengalami gastroenteritis dengan status gastroenteritis diperoleh bahwa dari 41 ibu yang memiliki balita yang mengalami gastroenteritis yang menerimadukungan bapak baik, ada sebanyak 1 balita $(2,4 \%)$ yang mengalami dehidrasi berat, sedangkan diantara ibu yang memiliki 
balita yang mengalami gastroenteritis yang menerima dukungan bapak buruk, ada 9 balita $(90 \%)$ yang mengalami dehidrasi berat. Hasil uji statistik didapatkan nilai $p$ value $=$ 0,000 , yang berarti ada hubungan yang signifikan antara dukungan bapak dengan status gastroenteritis pada balita ( $p$ value $<$ 0,05). Hasil analisis diperoleh Rasio Prevalensi $(\mathrm{RP})=9,6$ artinya dukungan bapak buruk kepada ibu yang memiliki balita yang mengalami gastroenteritis mempunyai risiko 9,6 kali balita yang gastroenteritis mengalami dehidrasi berat dibandingkan dengan dukungan bapak yang diterima ibu baik.

\section{KESIMPULAN}

Berdasarkan hasil penelitian yang telah dilakukan, maka di peroleh kesimpulan sebagai berikut:

1. Dukungan bapak pada ibu yang memiliki balita yang sedang mengalami gastroenteritis yaitu lebih tiga perempat ibu menerima dukungan bapak baik sebanyak 41 orang $(80,4 \%)$ dan hampir seperempat ibu yang memiliki balita yang mengalami gastroenteritis menerima dukungan bapak tidak buruk sebanyak 10 orang $(19,6 \%)$.

2. Status gastroenteritis pada balita yaitu lebih dari tiga perempat balita mengalami dehidrasi ringan sebanyak 42 orang $(82,4 \%)$ dan hampir seperempat balita mengalami dehidrasi berat sebanyak 9 orang $(217,6 \%)$.

3. Ada hubungan yang signifikan antara dukungan bapak yang diterima ibu yang memiliki balita yang mengalami gastroenteritis dengan status gastroenteritis pada balita ( $p$ value $<0,05)$. Hasil analisis diperoleh Rasio Prevalensi $(\mathrm{RP})=9,6$ artinya dukungan bapak buruk kepada ibu yang memiliki balita yang mengalami gastroenteritis mempunyai risiko 9,6 kali balita yang gastroenteritis mengalami dehidrasi berat dibandingkan dengan dukungan bapak yang diterima ibu baik.
SARAN

1. Keluarga

Diharapkan keluarga lebih aktif dalam mencari informasi tentang pentingnya dukungan bapak kepada ibu dalam melakukan perawatan bagi balita yang sedang mengalami penyakit gastroenteritis untuk mencegah terjadinya dehidrasi berat.

2. Perawat

Diharapkan perawat atau tenaga kesehatan lebih aktif dalam memberikan penyuluhan bagi bapak-bapak yang masih kurang memahami atau mengetahui pentingnya dukungan bapak kepada ibu yang memiliki balita yang sedang mengalami gastroenteritis.

3. Pelayanan kesehatan (puskesmas)

Diharapkan Puskesmas Luahagundre dapat menjadikan hasil penelitian ini untuk pertimbangan dalam usaha mencegah terjadinya dehidrasi berat pada balita yang mengalami gastroenteritis.

4. Peneliti Selanjutnya

Diharapkan bagi penelitian selanjutnya agar dapat melakukan penelitian yang lebih mendalam/spesifik lagi tentang hubungan antara dukungan bapak pada ibu yang memiliki balita dengan status gastroenteritis.

\section{DAFTAR PUSTAKA}

Anik, M. (2010). Ilmu Kesehatan Anak dalam Kebidanan. Jakarta: Trans Info Media.

Depkes RI. (2010). Pemantauan Pertumbuhan Anak di Masyarakat. Jakarta

Depkes RI. (2011). Buletin Jendela Data dan Informasi Kesehatan: Diare.

Dewi, V. N. L. (2010). Asuhan Neonatus Bayi dan Anak Balita, Salemba Medika: Jakarta.

Duci, V., \& Tahsini, I. (2010). Perceived Social Support and Coping Styles as Moderators for Levels of Anxiety, Depression and Quality of Life in Cancer Caregivers; a Literature Review. Euroropean Scientific Journal. Diakses tanggal 20 April 2018. 
Friedman, M.M., Bowden, R.V., \& Jones, G.E. (2010). Buku Ajar KEPERAWATAN KELUARGA; Riset, Teori, \& Praktik. Edisi 5. Jakarta: EGC.

Hidayat, A.A. (2009). Pengantar Ilmu Keperawatan Anak. Jakarta: Salemba Medika.

Kasman. (2010). Faktor-Faktor yang Mempengaruhi Kejadian Diare di Puskesmas Air Dingin Kecamatan Koto Tangah Kota Padang Sumatera Barat. Skripsi. Medan: FK USU.

Kemenkes RI. (2011). Situasi Diare di Indonesia. Dari: www.depkes.go.id, diakses tanggal 2 Desember 2013

Kemenkes RI. (2013). Profil Kesehatan Indonesia. Jakarta: Sekretaria Jenderal.

Newel, S., \& Meadow, S. (2008). Gastroenterologi. Jakarta: Erlangga.

Ngastiyah. (2010). Perawatan Anak Sakit. Edisi 3. Jakarta: EGC.

Notoatmodjo, S. (2010). Metode Penelitian Kesehatan. Jakarta: Rineka Cipta.

Pender, N.J., Murdaugh, C.L., \& Parsons, M.A.(2006). Health promotion in nursing practice (5 th ed). Upper Saddle River, NJ: Pearson Prentice Hall.

Pusponegoro, D.H., Hadinegoro, R.S., \& Firmanda, D. (2010). Standar Pelayanan Medis Kesehatan Anak. Edisi 3. Jakarta: IDAI.

Riskesdas. (2013). Badan Penelitian dan Pengembangan Kesehatan Kementerian Kesehatan RI. Jakarta: Kemenkes.

Setiadi. (2008). Konsep \& Proses Keperawatan Keluarga. Yogyakarta: Graha Ilmu.

Setiadi. (2012). Konsep Dan Penulisan Riset Keperawatan. Yogyakarta: Graha Ilmu.

Soetjiningsih, R.G. (2013). Tumbuh Kembang Anak. Edisi 2. Jakarta: EGC.

Subagyo., \& Santoso. (2011). Faktor-Faktor Resiko Kejadian Diare Akut Pada
Balita: Studi Kasus di Semarang. Dari: http://www.pdffactory.com.

Sulisnadewi, NL. K. (2011). Efektivitas Pendidikan Kesehatan Keluarga Terhadap Peningkatan Kemampuan Ibu Dalam merawat Anak Diare Di RSUP Sanglah Dan RSUD Wangaya Denpasar, Dari: digilib.unimus.ac.id.

Sulistyoningsih, H. (2011). Gizi untuk Kesehatan Ibu dan Anak. Jakarta: Graha Ilmu.

Sunarti, E. (2010). Mengasuh dengan Hati Tantangan yang Menengah . Jakarta: Media Kompolindo.

Suratmaja, S. (2010). Kapita Selekta Gatroenterologi. Jakarta: Sagung Seto.

Suriadi. (2009). Asuhan Keperawatan pada Anak. Edisi 1. Jakarta: EGC.

UNICEF. (2012). Ringkasan Kajian Air Bersih, Sanitasi \& Kebersihan. Dari: www.unicef.org.

UNICEF \& WHO. (2009). Diarrhoe: Why Children are still dying and what can bedone.

Dari: www.who.int/maternal_child_adolescent /documents/ 97892415984 15/e/

Uripi, V. (2006). Menu Sehat untuk balita. Jakarta: Puspa Swara.

WHO. (2009). Pelayanan Kesehatan Anak di RumahSakit.

Dari: http://www.gizikia.depkes.go.id/wpcontent/upl.

World Gastroenterology Organisation Global Guidelines. (2012). Accute Diarrhea in Adults and Children: a Global Perspective. Dari: http://www.worldgastroenterology.org.

Wong, D.L., Hockenberry, M., Wilson, D., Winkelstain, M,L., \& Schwartz. (2009). Buku Ajar Keperawatan Pediatrik. Volume 2. Jakarta: EGC. 